\title{
Towards the 'secondary worlds' in Henze's opera Elegy for Young Lovers
}

\author{
Rumo aos "mundos secundários" na ópera \\ Elegy for Young Lovers de Henze
}

Cinthia Pinheiro Alireti

Universidade Estadual de Campinas alireti@unicamp.br 


\section{Summary}

This article attempts to trace the dramatic-musical origins of the opera in three acts Elegy for Young Lovers (1961), with music by the German composer Hans Werner Henze and libretto by Auden and Kallman. By researching literary and theoretical sources on this work, with emphasis on the authors' own writings, it was examined the extrinsic resources that contributed to the constitution of the internal dramatic structure. These resources are, on the one hand, cultural influences that interacted in the construction of the artistic identity of the work and, on the other hand, conventions borrowed from other traditions, such as the topics of the lyrical repertoire, the concepts of primary and secondary worlds of fiction literature, and possible references to known personalities, which served as inspiration for the characterization of certain roles. It was found that extrinsic resources, besides contributing to the dramatization processes in opera, also play an important role in the elaboration of an underlying didactic discourse.

Keywords: Contemporary opera; pluralism; metalanguage; Hans Werner Henze; topics.

\section{Resumo}

Este artigo tem por objetivo traçar as origens dramático-musicais da ópera em três atos Elegy for Young Lovers (1961), com música do compositor alemão Hans Werner Henze e libretto de Auden e Kallman. Através da pesquisa de fontes literárias e teóricas sobre esta obra, com ênfase nos escritos dos próprios autores, foi examinada a existência de recursos extrínsecos que contribuíram para a constituição da estrutura dramática interna. Estes recursos se tratam, por um lado, de influências culturais que interagiram na construção da identidade artística da obra e, por outro lado, de convenções emprestadas de outras tradições, tais como os tópos do repertório lírico, os conceitos de mundos primários e secundários da literatura de ficção, e possíveis referências a personalidades conhecidas, as quais serviram de inspiração para a caracterização de personagens. Verificou-se que recursos extrínsecos, além de contribuírem para os processos de dramatização na ópera, também desempenham um papel importante na elaboração de um discurso didático subjacente.

Palavras-chave: Ópera contemporânea; pluralismo; metalinguagem; Hans Werner Henze, tópos. 


\section{A German opera, an English libretto}

On May 20, 1961, the opera Elegy for Young Lovers, by Hans Werner Henze, premiered at the Schlosstheater Schwetzinger, during the Schwetzinger Festival, under the direction of Heinrich Bender and the production of the composer himself. Both this and the following productions, repeated in other parts of Germany and in Zurich, were executed with the German version of the text, translated by Ludwig Landgrafin. Only later in the year, the original English libretto by W. H. Auden and Chester Kallman was heard for the first time in Glyndebourne, yet only partially (ROTH, 1979, p. 100).

An English libretto with music written by a German composer. Would this idea have been the result of the friendship between Henze, Auden and Kallman, established during the first years of the composer in Italy? Or was the interaction between these two cultures intentionally used to recreate a third one, that of 19th century Italian opera? Perhaps the use of extrinsic materials from different traditions and their interaction with the main dramatic structure, which is the basis of Elegy's pluralist language, loaded with musical and literary references, was intended for the construction of secondary worlds, as described by Auden (AUDEN, 1984). Borrowing material from other traditions is a procedure used in musical composition since the Renaissance period, which became a popular trend in postmodern languages, illustrated through the eclectic style of Berio, Del Tredici, and Crumb. This article aims to identify extrinsic resources used in Elegy for Young Lovers, using Henze and Auden's writings as a starting point, and to verify their connection with the composer's compositional process, in order to trace a path to the musical origins of the opera. In this sense, this research can represent the first step towards future studies in the field of musical semiotics, especially concerning possible uses of intertextuality and semantic interaction integrating the musical discourse.

Not only Henze's growing lack of interest in the German artistic environment, but also that particular historical context may have encouraged the composer's inclination to set librettos written in English. It is well known that, during the Nazi Germany and the later economic miracle, the serialism of Stockhausen-also of Boulez, and Nonoco-existed with foreign influences, as can be seen by the enormous success of Britten's Peter Grimes, premiere in 1945, and by the influence of Soviet models and the "social realism" on the GDR opera, after Stalin's death (COOKE, 2005, p. 168-164).

Another possible reason for detaching himself from his German roots may be related to his personal and political disillusionment with his country, which led him to move in 1953 to a seaside house in Forio, on the Island of Ischia, in Italy. As he writes,

The period of political reconstruction around and after 1950 was also that leading up to the banning of the KDP (German Communist Party); old comrades, who had been imprisoned by the Nazis, were locked up again. I had never heard anyone mention this in musical circles. Music is, after all, unpolitical! The ban, incidentally, also killed off workers's music and the democratic tradition of folk song [...] In addition there was my social isolation as a homosexual. For it was then socially impossible to be a homosexual as this was considered a pathological state... (HENZE, 1982, p. 50-51). 
To increase his disbelief in the German artistic environment, his economic situation also became precarious in 1949, when he lost his job with Heinz Hilpert at the Deutsches Theater in Constance. According to him, the theatre went bankrupt because Hilpert refused to make popular concessions, insisting on presenting plays of classic status (HENZE, 1982, p. 49)

In Italy, he had the opportunity to study the local culture and language and reassess his compositional methods and goals, especially his approach to the dodecaphonic style as opposed to simplification in his music, as he write in 1980,

On a reflection, I can begin to understand my differences with the Darmstadt School. It may seem a bit far-fetched, but I have often thought that their attempt to make music non-communicative had something to do with the ruling class's belief that art is a thing apart from life, better kept that way, and without any social dimension. The reason why this 'non-communicative' tendency, which possessed a mystical, indeed an expressly Catholic element, was so vigorously promoted, was, I think, the desire to prevent people from seeing music as simple, concrete and comprehensible communication between human beings. (HENZE, 1982, p. 49).

\section{A chamber opera in three acts}

In the Genesis of a Libretto, a short postscript text added by W. H. Auden to the published libretto (FULLER, 1998, p. 481), which was included in the music score, explains that Henze wanted to compose "a 'chamber' opera for a small cast with no chorus, and for a small subtle orchestra" (HENZE, 1989, p. 61). Later, in Secondary Worlds (AUDEN, 1984, p. 101), Auden adds that Henze asks the librettists to consider writing a work that could be executed entirely with only one scenario.

The restriction of instrumental and vocal forces was certainly not related to the economy of sources, as we see in some of the operas composed around the same period. The luxurious Der junge Lord, premiered only few years after (1965), required 25 soloists, multiples choruses and ensembles; this work marked Henze's return to Germany (PORTER, 1969, p. 1029). The Bassarids (1966), another result of Henze's collaboration with Auden and Kallman, also demands gigantic forces and is written in through-composed style (NORTHCOTT, STRAVINSKY, HENZE, 1993, p. 7). However, it is possible that Henze's choice of chamber settings might be connected in a way to his wish to write a "number opera"; in Music and Politics, Henze says that his collaboration with Auden and Kallman in the writing of Elegy was inspired by their mutual love for nineteenth-century opera and the product of this collaboration should refer to this genre in an opera "expressed in set numbers and the style of ensembles" (HENZE, 1982, p. 107). ${ }^{1}$

The chamber conception of Elegy unfolds in four chamber levels:

1) the whole drama is presented in a single set, an Inn in Austria, 
2) the work requires only a few vocal soloists, no choir,

3) and a chamber instrumental ensemble, instead of a full-orchestra. As we see in Tab. 1, even if the score calls for a huge percussion set, only one of each wind and string instrument is required:

\begin{tabular}{|c|c|}
\hline $\begin{array}{l}1 \text { gran flauto (muta in ottavino, flauto contralto e } \\
\text { flauto doce contralto ad lib.) } \\
1 \text { corno inglese (all fine del } 3 \text {.atto muta in oboe) } \\
1 \text { clarinetto in si b (muta in clarinetto basso) } \\
1 \text { sassofono contralto in mi b } \\
1 \text { fagotto } \\
1 \text { corno in fa } \\
1 \text { tromba in do e re } \\
1 \text { trombone }\end{array}$ & $\begin{array}{l}2 \text { violini } \\
1 \text { viola } \\
1 \text { violoncello } \\
1 \text { contrabasso }\end{array}$ \\
\hline $\begin{array}{l}\text { timpani } \\
\text { campanelli a tastiera } \\
\text { celesta } \\
\text { marimbafono } \\
\text { vibrafono } \\
\text { flessatono [può essere sostituito da uno strumento } \\
\text { elettronico] }\end{array}$ & $\begin{array}{l}\text { mandolino } \\
\text { chitarra } \\
\text { arpa piano forte a coda (senza } \\
\text { coperchio) }\end{array}$ \\
\hline \multicolumn{2}{|c|}{$\begin{array}{l}\text { Batteria I } \\
1 \text { tomtom (piccolo, medio, grande), tamburo militare con la corda (c.c.), tamburo militare } \\
\text { senza la corda (s.c.), wood-block, metal-blocks (da percuotere con bacchette di } \\
\text { silofono) }\end{array}$} \\
\hline \multicolumn{2}{|c|}{$\begin{array}{l}\text { Batteria II } \\
3 \text { crotali, piatti sospesi (piccolo, medio, grande), } 2 \text { piatti (a due), } 3 \text { triangoli (piccolo, } \\
\text { medio, grande), } 3 \text { campane da gregge (piccolo, medio, grande), gran cassa }\end{array}$} \\
\hline $\begin{array}{l}\text { Batteria III } \\
3 \text { tamtam (piccolo, medio, grande), gran cassa, ma } \\
\text { medio, grande), } 3 \text { bongo (acutissimo, più acuto, me }\end{array}$ & $\begin{array}{l}\text { s, } 3 \text { tamburi baschi (piccolo, } \\
\text {, } 6 \text { campane tubolari }\end{array}$ \\
\hline
\end{tabular}

Tab. 1 Elegy for Young Lovers' list of instrumentation, as described in the score (HENZE, 1989)

4) Henze structures the opera in numbers, ${ }^{2}$ alluding to the traditional 19th-century operas structures. In this sense, drama and music were organized in small numbers, instead of developing in a through-composed style.

2 Curiously, Stravinsky, who was highly praised by Henze, also intended to "write an opera of the Mozart kind" when he asked Auden and Kallman to write the libretto of the Rake's Progress, however, Stravinsky's reasons were instead based on the neoclassical expression of the eighteenth century engravings by Hogarth (AUDEN, 1984, p. 98). 


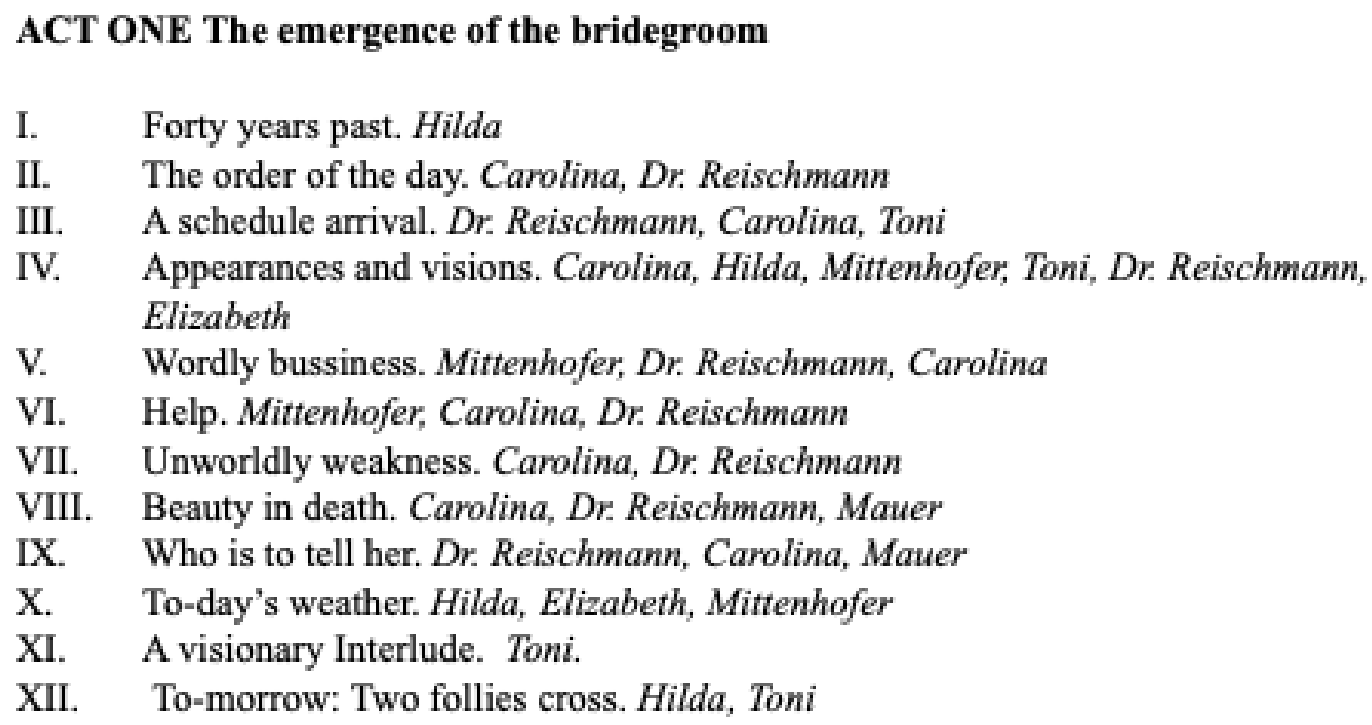

\section{ACT TWO The emergence of the bride}

I. A passion. Toni, Elizabeth, Carolina

II. Sensible talk. Dr. Reischmann, Toni, Carolina, Elizabeth

III. Each in his place. Dr. Reischmann, Toni, Carolina, Elizabeth

IV. The master's time. Carolina, Toni, Elizabeth, MittenhoferPersonal questions. Mittenhofer, Elizabeth, Carolina

V. The troubles of others. Elizabeth, Toni

VI. What must be told. Elizabeth, Toni, Carolina

VII. The wrong time. Elizabeth, Toni, Mittenhofer, Dr. Reischmann, Carolina

VIII. The bride. Hilda, Mittenhofer, Carolina, Toni, Dr. Reischmann, Mauer

IX. The young lovers. Mittenhofer, Elizabeth, Hilda, Toni, Dr. Reischmann, Mauer

X. The flower. Toni, Elizabeth, Dr. Reischmann, Mittenhofer, Hilda

XI. The vision of to-morrow. Elizabeth, Toni, Hilda, Dr. Reischmann, Mittenhofer, Carolina, Mauer

XII. The end of the day. Mittenhofer, Hilda

\section{ACT THREE}

Man and wife

I. Echoes. Elizabeth, Toni, Hilda, Dr. Reischmann, Mittenhofer, Carolina

II. Farewells. Hilda, Carolina, Mittenhofer, Dr. Reischmann

III. Scheduled departures. Hilda, Carolina, Mittenhofer, Dr. Reischmann

IV. Two to go. Mittenhofer, Carolina, Mauer

V. Mad happenings. Mittenhofer, Carolina

VI. A change of scene. Elizabeth, Toni

VII. Man and wife. Elizabeth, Toni

VIII. Toni and Elizabeth. Elizabeth, Toni

IX. Elegy of young lovers. Mittenhofer, Carolina

(Hilda, Elizabeth, Toni, Dr. Reischmann) 


\section{Inside the libretto}

Elegy's libretto is dedicated "to the memory of Hugo von Hofmannsthal, Austrian, European and Master Librettist, and to 'its three makers, Wystan H. Auden, Chester Kallman, Hans Werner Henze'" (HENZE, 1989, iii). Although the main character of the opera is an Austrian poet, who lives in an inn called Der Schwarze Adler in the Austrian Alps, during the year of 1910, the dedication seems to play only a generic role in the conception of the libretto. The poet in the opera could not be an image of Hofmannsthal simply because it would not be appropriate to base the main role, portrayed as the spirit of the narcissistic nineteenth-century artist, on the praised poet of the dedication. What seems to be the closest relation between the opera and the dedication to Hofmannsthal is the aim for psychological drama, as remarks Auden, in the Genesis of a libretto,

Our ambition in writing the libretto has been to see how much psychological drama and character interest we could make compatible with the conventions of the operatic medium, and the Great Ancestors whose blessing we continually found ourselves invoking were lbsen and Hofmannsthal (HENZE, 1989, p. 63).

The operas calls for six vocal soloists, one spoken character, and silent servants. In the beginning, each character suffers from one obsession, but later on, the idea of a single hero, the poet, around whom everyone would be connected, shadows the characters' individual obsessions (HENZE, 1989, p. 61).

\section{Gregor Mittenhofer \\ (baritone) a great poet, the opera hero, \\ the portray of the artist genius of the nineteenth century and early twentieth century}

\begin{tabular}{|c|c|}
\hline $\begin{array}{l}\text { The young lovers-the poet's source of } \\
\text { inspiration II }\end{array}$ & The poet's caregivers: \\
\hline $\begin{array}{l}\text { Elisabeth Zimmer (soprano) } \\
\text { his mistress }\end{array}$ & $\begin{array}{l}\text { Carolina von Kirchstetten (contralto) } \\
\text { the poet's secretary, his house keeper }\end{array}$ \\
\hline $\begin{array}{l}\text { Toni Reischmann (lyric tenor) } \\
\text { his grandson, the doctor's son }\end{array}$ & $\begin{array}{l}\text { Dr. Wilhelm Reischmann (bass) } \\
\text { a doctor, an admirer, responsible for keeping } \\
\text { him in good health and youthful vigor }\end{array}$ \\
\hline The prophet-the poet's source of inspiration I & A messenger: \\
\hline $\begin{array}{l}\text { Hilda Mack (coloratura soprano) } \\
\text { a permanent resident of the inn, who goes into } \\
\text { trances and have visions, waiting for } \\
40 \text { years the return of her husband }\end{array}$ & $\begin{array}{l}\text { Josef Mauer (speaker), an Alpine Guide } \\
\text { Servants in the inn (silents) }\end{array}$ \\
\hline
\end{tabular}

Tab. 3 Descriptions of the characters and their connection to the poet, as listed in the score (HENZE, 1989) 
Perhaps, the most interesting description of the characters lies in Mittenhofer's text, in the last scene of act II, where, by scorning the others, he ends up portraying his own selfish and narcissistic personality, creating a metalinguistic treatment to the text:

\author{
BAH! What a bunch! What a scrubby bouquet! \\ The heart sinks. Look! [...] \\ A lunatic witch \\ Who refuses to be mad; an aristocratic bore \\ Who wants to play Nanny to her private Emperor; \\ A doctor who needs a rhyming guinea-pig \\ To make him famous, and make newly-rich \\ His motherless whelp, that rutting little prig \\ Who imagines it's rebellion to disobey \\ His father; AND a fatherless bitch \\ Who found a papa-dog from whom to run away! \\ Why don't they just blow up and disappear! \\ Why don't they all DIE? (HENZE, 1989, p. 45-46)
}

From the characters initial obsessions, it perpetuates the impossible love of the young couple. Masquerading as a great lady, she is, in fact, hired as a lady's maid on her vacations at the inn, that is, despite her aristocratic instincts, she was not born one. Nevertheless, Toni, a young man of a good family, falls in love with her and she with him, without knowing the truth. Elizabeth would have to die before he discovers her true social status (HENZE, 1989, p. 61).

Hilda Mack's character conveys the second obsession. She lives in the past, waiting for her husband's return, who disappeared in the glaciers for forty years. A greatly rich character, Hilda Mack acts in different contextual levels: 1) she is a woman who lives from an expectation and also lives from the past, 2) she embodies the character of Miss Havisham in Dicken's Great Expectation (HENZE, 1989, p. 61), 3) and because of her visions, she plays a commentator's role, like a character from a Greek chorus of the ancient operas.

Although Hilda's role remains secondary until the end, the importance of her character may have been greater than its libretto lines. At the end of Genesis of a Libretto, Auden suggests that the figure of the poet was based on real events, "As a matter of fact, the only things about him which were suggested to us by historical incidents were drawn from the life of a poet - no matter whom - who wrote in English" (HENZE, 1989, p. 63). Earlier in the text, he sums up the theme of Elegy in two lines by Yeats, "The intellect of man is forced to choose / Perfection of the life or of the work" (HENZE, 1989, p. 63). Whether Yeats served as inspirations for the creation of the libretto or whether this quote represented just a mere coincidence might remain a secret. Curiously, Yeats had a wife from whose mediumistic gifs he profited, which makes Hilda Mack a possible clue to the identity of the poet, on whose life the libretto of Elegy might have been based (AUDEN, 1984, p. 104). 


\section{Musical connections}

From a structural point of view, Hilda's visions also serve to pace the drama, functioning as a kind of common motif, whose recognition potential was produced during the flow of the opera. Yet, other occasions within the opera, where external material is recognized by the listener, also seem to play an important role in the pace of listening, ${ }^{3}$ as long as these resources are recognisable. Opera conventions, the so-called "topoi", or "topics", ${ }^{4}$ which appear extensively in 19th-century operas (EDGECOMBE, 2014, p. 67-80), work as points of cadence inside the opera, bringing the listener to a recognized territory. The first one of these moments occurs right at the opening of the opera, where Hilda Mack sings a mad lament. The composer's choice of an obbligato flute and a soprano coloratura to perform this number refer directly to the topic of madness, reminding us of the famous mad scene in Donizetti's Lucia di Lammermor (HENZE, 1982, p. 107). Besides referring to 19th century opera, the recreation of a crazy scene may also indicate Britten's influence on this composition, which was considerably in vogue at that time. ${ }^{5}$ It is important to notice that, except for this first reference, topics appear to function only as thematic stock material in the opera, and not as products of intertextuality, as defined by Kristeva; ${ }^{6}$ as to say, no traces of reworking of style or transformation of referential material were identified at this moment. ${ }^{7}$

Another common topic of the 19th century opera referred to in Elegy is the indispensable "love duet", which appears in act III, scene VIII. The interesting thing about this number is that it consists of a love song and a prayer, as we will see later in this article. In this sense, the duet alludes to two operatic topics, the love duet and the preghiera, at the same time.

The Storm interlude is also a well-known opera topic used in Elegy, which appears in act III, scene VI, "Change of scene", right before the young lovers realize that their love was only an illusion (FULLER, 1998, 482). Storm scenes have been heard in musical dramas since the baroque period, but this topic has become truly consecrated as an orchestral interlude in Britten's opera Peter Grymes (June 1945, London, Sadler's Wells), which might be another clue to Britten's influence on Henze in the writing of this opera. Not only Henze knew Peter Grymes, he was also considerably touched by its interludes:

3 According to Auden, double meanings should be avoided in libretto writings, because a complicated metaphor would take more time to be understood than the music could possibly show, disrupting the pace of the opera. He says, "I suspect it has to do with musical tempi being generally slower than speech tempi - that composers find short lines of verse easier to set than long ones" (AUDEN, 1984, p. 92).

4 "[...] while the extension of a musical topos consists of a set of musical works, passages, or the like, the intention of the topos - its "meaning" to a given musical listener, or "signified"—-would better be approximated by what we have called semantic fields" (HUIVINEN, KAILA, 2015, p. 237).

$5 \quad$ Britten, who also collaborated with W. H. Auden, was a close friend of Henze. The latter had even referred to Britten as "Ben", when dedicated his Kammermusik (1958) to the English composer (HENZE, 1982, p. 254). Out of coincidence or not, Britten included a parody of a mad scene in his Midnight Summer Dream, premiered just one year before Henze's Elegy.

$6 \quad$ Kristeva wrote "Any text is constructed as a mosaic of quotations, any text is the absorption and transformation of another text" (KRISTEVA, 1969, p. 85, apud MICZNIK, 2000, p. 23).

$7 \quad$ The opposite of this idea is Micznik's interpretation of the intertextuality between Berlioz's love scene in Roméo et Juliette and Beethoven' String quartet, op. 18, n.1 (MICZNIK, 2000, 21-61). 
One of the first pieces of modern music that I heard as a student was Peter Grimes, in Mannheim in 1946. What struck me above all were the orchestral interludes, which had an organ-like beckoning and resonant quality, informed by the sense of remoteness; they seemed to me like echoes thrown back by the horizon of the sea. [March 1979] (HENZE, 1982, 253)

Whether regarded as a simple theatrical material or reminiscences of Schaeffer's musique concrète, realistic sounds appears as musical characters in the opera, contrasting with the nineteenth-century Italian opera influences. As explains Henze, the clock-chimes appear in the ending and beginning of scenes, dividing time periods and symbolizing the protagonist's obsession with time (HENZE, 1982, 253). The high point of this procedure appears in act III, scene VI, when Carolina realizes that she acted as an accomplice to murder. At this point, the psychological time stops and Carolina enters in an introspective world. The clock with its mechanical pulse, depicted by a texture made of the repetition of quiet and short notes, represents, so to speak, a theatrical means of expression of time, antagonized by the poetic idea of eternity, symbolized by the glacier, where young lovers "crystallize" their love.

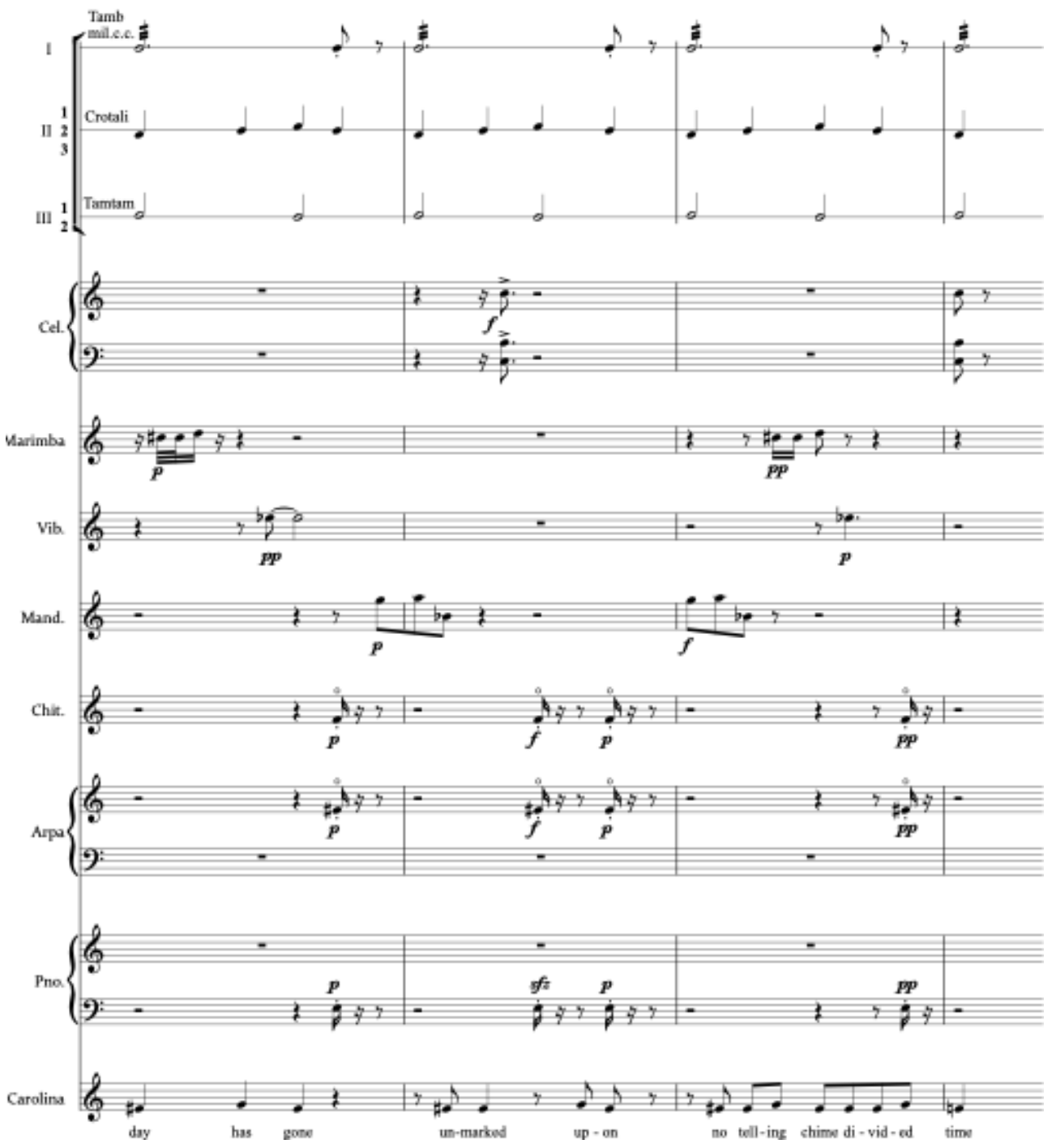

Fig. 1. Act III, scene VI, "mechanic" texture imitating a clock working 
Besides the clock, other realistic sounds mark the appearance of threatening situations, according to Henze, like "The whistle of train in act I, at the first appearance of Toni Reischmann, the cowbell in act II that accompanies the tipsy Hilda Mack, the metallic clatter of a heavy object that falls to the ground at the very moment that Mittenhofer tells his murderous lie" (HENZE, 1982, 107). The only occasion where realistic sounds seem to act not only as a dramatic resource but also as musical material in opera is the tape recording of the bells ringing in fade out at the end of the love duet of act III, perhaps reminiscent of Henze's visit to the Tonstudios of Pierre Schaeffer and Pierre Henry in Paris ten years earlier (MGG2, p. 1326).

Briefly remarking, the instruments also contribute to the dramatization of the characters and the situations. Obligatory solo instruments portray the mental state of a character, represented in the vocal lines, while the other instruments of the orchestra, especially the percussion, create atmospheres, written as a kind of concerto grosso (HENZE, 1982, p. 108). Each obbligato instruments is related to the tessitura of one character (HENZE, 1982, 115-116):

The English horn is given to Countess Carolina, a contralto. In Henze's words, "it [the English horn] has sometimes enabled us to hear her unspoken thoughts; it becomes silent, while she becomes an automaton, totally without feeling, a living clock..."

The poet, a baritone, "The Master, the powerful one, Dracula", expresses his emotions through the three brass instruments available in the orchestra. The horn shows his contemplative and gentle state of mind, and also his affinity with the forest and nature. The trumpet portrays him as the "proclaimer and ranter and hysteric" and the trombone shows his role as "the hallowed man of wisdom and wild boar."

The doctor, a bass, is "regarded as a bon vivant, whose joviality testifies to a bad conscience and cowardice. To underline this he has been allotted a bassoon, whose jollity has something artificial... and for the occasional outburst of explicit sentimentality a saxophone in addition."

Toni, a lyrical tenor, is associated to a "softly romantic and discontented viola."

The flute is given to Hilda, a coloratura soprano, evidencing her characterizing madness by the association of this instrument to the mad scene topic.

Elisabeth, a soprano, expresses her character with the sound of a violin.

The spooky sound of a flexatone appears three times in the opera, associated to the power and dreadfulness of the poet's ideas. At the poet's first entrance, the flexatone "plays nine notes of the complete twelve-tone row and creates a horror-film atmosphere. Returns only once during the $2^{\text {nd }}$ act, at the moment when the poet is planning the crime, and once again when the crime is committed in the $3^{\text {rd }}$ act" (HENZE, 1982, 116).

The guitar and the piano assume the role of orchestral instruments in the opera, except for the use of the piano as accompaniment of the secco recitative in act $I$, scene II. Moreover, nothing seems to indicate the use of these instruments to portray social status, as Robert Hatten mentions in his article on Henze's We come to the River: "In the opera [We come to the River], the guitar is opposed to the harp, the latter being treated as source music (trite tonal arpeggios) in association with 'effete bourgeois art'" (HATTEN, 1990, p. 298). 
Finally, a brief comment on the melodic writing used in Elegy, which can be organized into three gradations, according to Henze's writings, going from references to the post-modern musical language of the 1950 s to the simplicity of folk songs, according to dramatic needs:

Hilda's distinct melodic writing (Fig. 2), imitated by the alto flute in the opening scene (see Fig. 3), and later transposed to Mittenhoferin's cursing singing of the last scene of act II (see Fig. 4):

Hilda's music is kept in the idiom of the 1950s, not only in the instrumentation (obbligato flute, accompanied by harp, celesta and tuned percussion) but also in flow: wide leaps between intervals, coloraturas, a preponderance of sevenths and ninths [...] after she is cured, this kind of music still clings her [...] This produces the impression that tones of warmth and humanity are circumstantial or even impossible in this kind of music [...] (HENZE, 1982, p. 112-113).

Melodic lines characterized by the predominance of melodic intervals, like "ascending and descending fourth, and the intervals of a sixth, minor second, major second, major sixth, and minor second" (HENZE, 1982, p. 112-113); found in Mittenhofer's lines, harmonic intervals as the open fifths in the love duet, and in the final chord of the piece $^{8}$ (see Fig. 5):

Simple cantabile melodies, using tonal and simple intervals, as in the beginning of act II, "seeming as though they would naturally end in folk song" (see Fig. 6) (HENZE, 1982, p. 117):
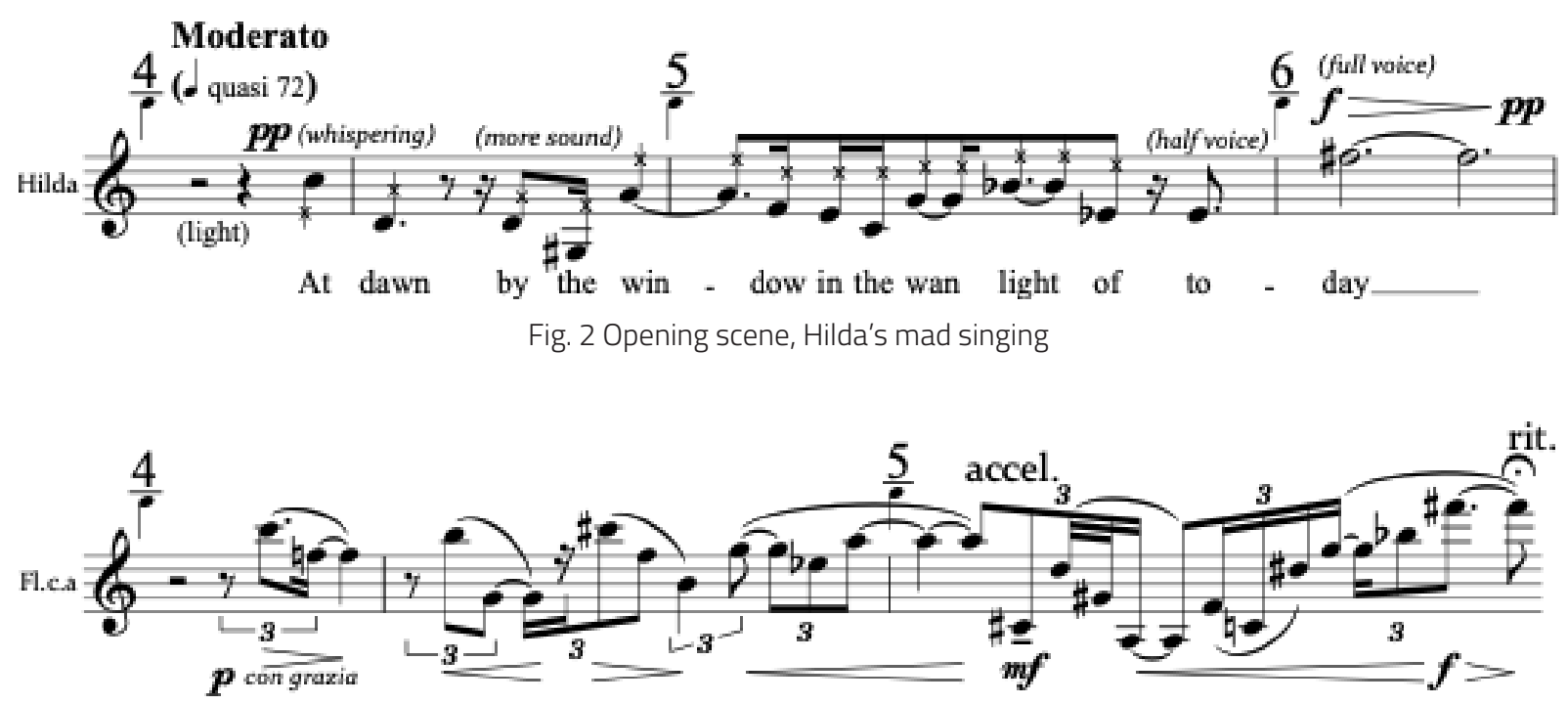

Fig. 3 Opening scene, the alto flute line, in dialogue with Hilda's singing 


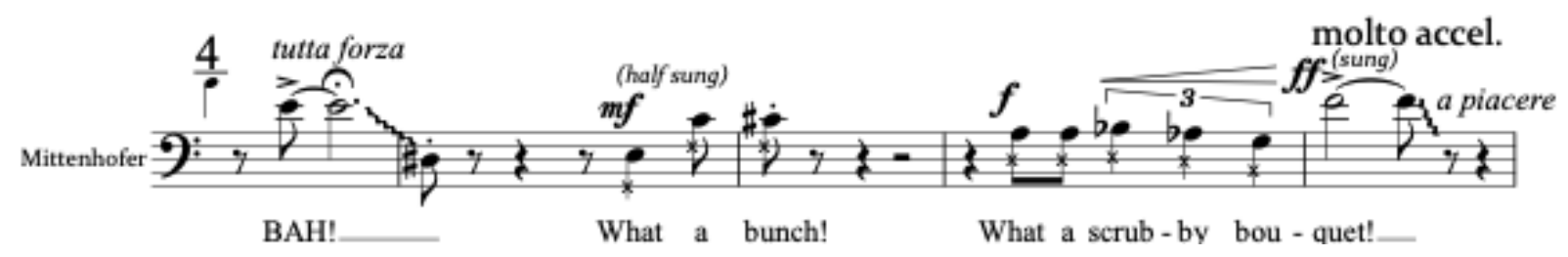

Fig. 4 Act II, scene XII, Mittenhofer's cursing singing in the style of Hilda's mad singing

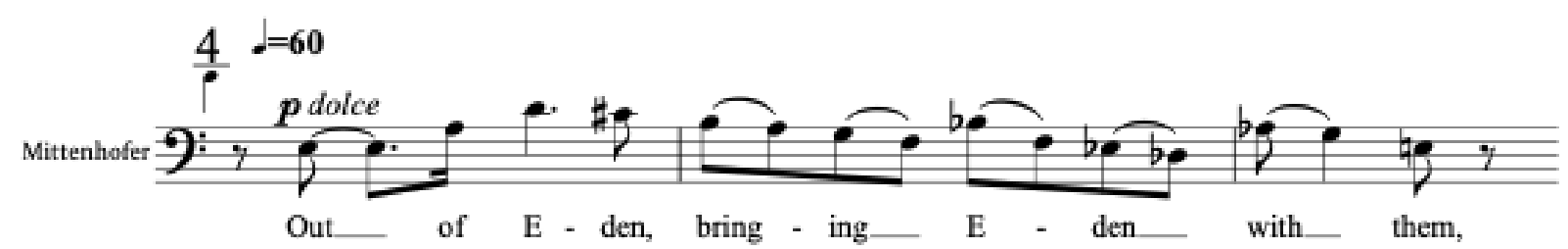

Fig. 5 Act II, scene X, Mittenhofer's melody with intervals of fourths and seconds

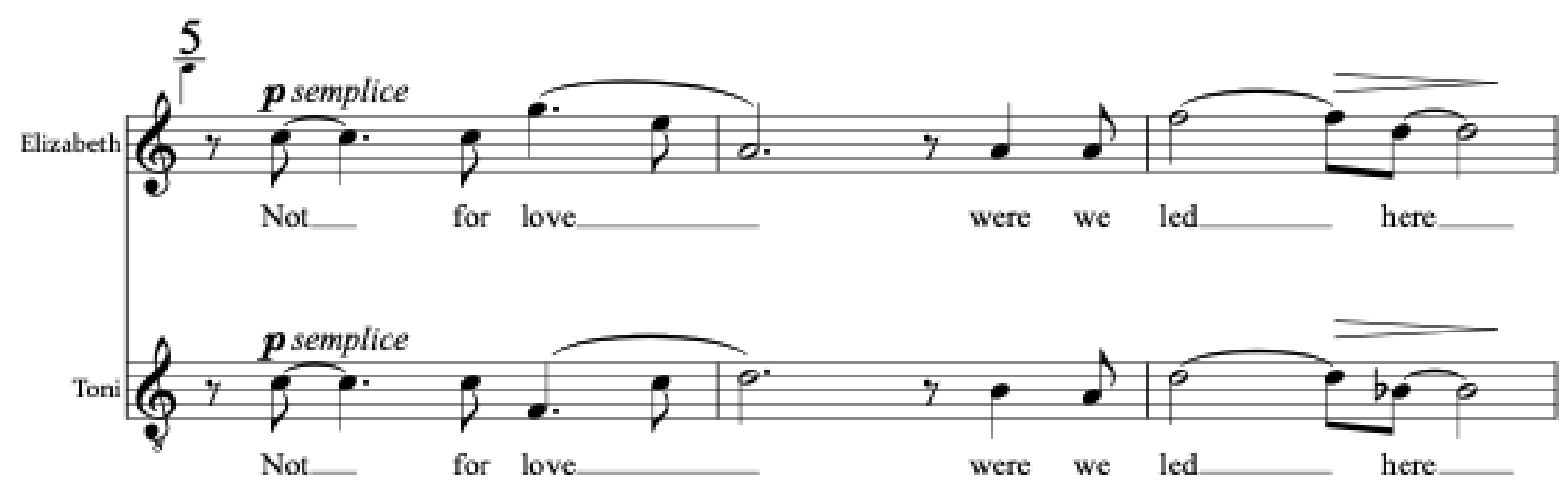

Fig. 6 Act III, scene VIII, the young lovers duet with triadic contours

\section{Into the secondary worlds of the plot}

Divided into two dramatic levels, the plot of Elegy for Young Lovers is, on the one hand, driven by dramatic issues related to the characters of the libretto and, on the other, by the story written by the poet. The initial scenario shows the poet living in an inn with his mistress Elisabeth, his secretary Lina and Hilda Mack, whose visions are his source of inspiration. Everything changes from two events happening in act l, which will considerably affect the poet's life. First, the news of the appearance of Hilda's husband's body on the glaciers, which will put an end to Hilda's trances and her obsession with the past, ceasing her visions. Second, the visit of Toni, son of his doctor, good friend and admirer, Dr. Reischmann. Toni and Elisabeth will fall in love, depriving the poet of his lover.

In act II, the poet becomes aware of the young lovers and pretends to accept their union, dedicating his Elegy to them. But he asks for a gift for his birthday, an Edelweiss, a flower that grows in the Hammerhorn. Knowing the bad weather conditions, the poet is actually sending the two lovers to end their story with their own deaths. Act III begins with gradual departures, Toni and Elizabeth leave for the Hammerhorn and the doctor and Hilda bid Lina farewell. Then Joseph Mauer, the alpine guide, comes on the scene to 
inform the poet and Lina of the bad weather, asking if anyone had gone to the mountains. The poet and Lina omit the young couple's departures, sealing their eternal complicity.

In the glaciers, Toni and Elizabeth realize that their story was only an illusory dream, and they supposedly die. The opera ends with the reading of the poet, with the dedication of his poem to the memory of the young couple.

The different plans created in the plot, on one level, by the facts in the main timeline, and on another level, by Hilda's visions, the poet's fictional writings, and the illusory love of Tony and Elizabeth, were probably inspired by Auden's ideas in his book Secondary Worlds (1968)..$^{9}$ This is how the author distinguishes the primary from the secondary world:

Present in every human being are two desires, a desire to know the truth about the primary world, the given world outside ourselves in which we are born, live, love, hate and die, and the desire to make new secondary worlds of our own or, if we cannot make them ourselves, to share in the secondary worlds of those who can (HENZE, 1982, 49).

Next, he describes the primary world as the objective universe outside ourselves, the social and public environment, which requires a social agreement to participate. On the other hand, the secondary world is private, it is built from subjectivity where art arises. Both worlds live side by side, distinguished by the contrasting visions of a Historian or a Poet:

The marriage in each of us, whether as writers or readers, between the Historian and the Poet, first began to run into serious difficulties in the seventeenth century, but it is only in the industrialized societies of the last hundred and fifty years, that, by the time most of us are twenty, the two have divorced [...] The consequences are only too obvious. The primary world as perceived by the divorced Historian, is a desacralized, depersonalized world where all facts are equally profane [...] The divorced Poet, on the other hand can find materials for building his secondary worlds only in his private subjectivity. His characteristic virtue, a sense of the sacred, the personal, becomes concentrated upon himself (HENZE, 1982, p. 82-83).

Considering the overall dramatic picture of Elegy for Young Lovers, it is possible to find at least three ways in which this work connects to Auden's ideas of "secondary worlds":

The plot develops from the construction of secondary story, it is a drama inside a drama. The opera is about the process of writing an elegy, the "live" creation of a secondary world. According to Henze, the opera essentially attempts to show the birth of a poem, in the process of being created during the three acts, and whose genesis starts at the beginning of the opera and will finish with the final public reading, shown in the last lines of the opera: 
Mittenhofer Your Serene Highness, Your Excellency the Minister of Culture, Ladies and Gentleman. I am going to open this reading with the last poem I have written, ELEGY FOR YOUNG LOVERS. It is dedicated to the memory of a brave and beautiful couple, Toni Reischmann and Elizabeth Zimmer who, as some of you know, perished recently on the Hammerhorn. "In death they were not divided" (HENZE, 1989, p. 59).

Three secondary worlds coexist in the play: the illusory world built by young lovers, the nostalgic world of Hilda Mack and the artistic and murderous world of the poet (WALTER, 1994, p. 238). Here is the passage where Toni and Elizabeth realize that their love is only part of a story:

\begin{tabular}{|c|c|}
\hline Elizabeth & Toni? \\
\hline Toni & Yes, dear. \\
\hline Elizabeth & $\begin{array}{l}\text { Tell me the truth } \\
\text { Is the hand you hold Elizabeth's hand? }\end{array}$ \\
\hline Toni & $\begin{array}{l}\text { tenderly } \\
\text { No, my dear, but the name will do. }\end{array}$ \\
\hline Toni & Elizabeth? \\
\hline Elizabeth & Yes, dear. \\
\hline Toni & $\begin{array}{l}\text { Tell me the truth } \\
\text { Is the hand you hold Elizabeth's hand? }\end{array}$ \\
\hline Elizabeth & $\begin{array}{l}\text { tenderly } \\
\text { No, my dear, but the name will do. }\end{array}$ \\
\hline Both & $\begin{array}{l}\text { Now we know. Now we are free } \\
\text { To die together and with good will } \\
\text { Say farewell to a real world (HENZE, 1989, p. 57). }\end{array}$ \\
\hline
\end{tabular}

When the poet passes from a mythical figure, credited as a genius, an inventive mind, to only a product of his social context, he starts to live in the primary and historical world (WALTER, 1994, p. 239). The extreme reactions of the bourgeois characters surrounding the artist, as exemplified by the role of Carolina, show the extent to which people are prepared to devote themselves to art and its creators, thus, establishing the imaginary distance created by society from a worshipped figure. According to Henze,

The problem of the elitist existence of the artist is shown in our opera in the form of a parable [...] Aesthetically speaking, the personal existence of the artist is accidental; the essential thing is his production [...] the artist-genius is morally bound by a sacred duty to exploit others whenever such exploitation will benefit his work [...] (HENZE, 1982, p. 110)

It is also possible to find in the opera small glimpses of "secondary worlds", created in the displacement of temporal realities, through references to past traditions. In Music and Politics, Henze mentions the "to-morrows" occurring in Act II as an allusion to Macbeth's soliloquy "that begins with the same words, and weave associations with the poor player and the tale by an idiot, full of sound and fury [...]" (HENZE, 1982, p. 106). Although Macbeth's soliloquy does not begin with "to-morrow" as he mentions, the expression "to-morrow" appears quite often in Shakespeare's text as a whole, especially at the time when Macbeth is informed of Lady Macbeth's death. Note the way "to-morrow" appears in the texts of the two authors: 


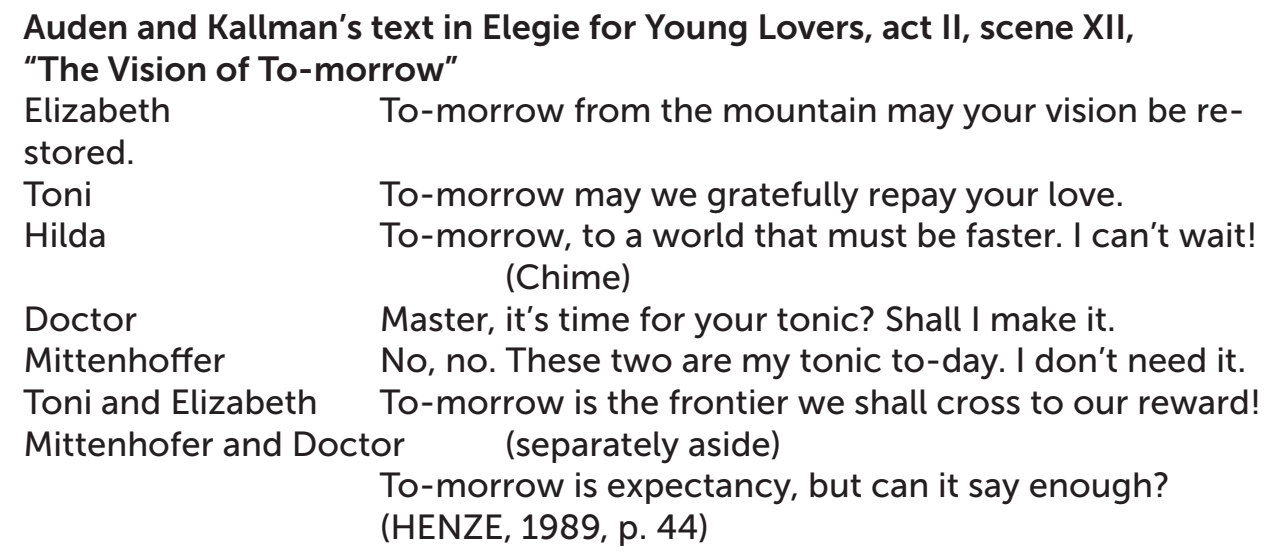

Shakespeare, Macbeth, act V, scene V

SEYTON The queen, my lord, is dead.

MACBETH She should have died hereafter;

There would have been a time for such a word.

To-morrow, and to-morrow, and to-morrow

$(5.5 .2373-2736)$

Another reference to cultural traditions of the past happens in act I, scene IV, when Elizabeth and Toni are introduced to each other. At this moment, Hilda has a vision of their fate, sealed with death and an illusory love, which will be illustrated in a gloomy song referring to the "falala" songs of spring, popular in the English Renaissance. Here is one fragment of the song:

She gave me flowers holy-white

That were not his to wear.

His kiss was like fever,

He held her forever

Only, only there,

An gave to me a tear to weep

Not hers alone to bear.

Falala...

They gave each other roses wild

From valleys they had not crossed.

Their kiss was two fevers,

In season the lovers

Found, alas, the cost:

When everything is lost for love,

Love too is also lost.

Falala...

She sits. Then she resumes as she begun.

Winter and Spring have met

Now on the slope, where,

Worried, the glacier

Moves down, revealing

Spring come to woe (HENZE, 1989, p. 15-16). 
References to the children's musical universe are disguised as mock texts in the libretto. An example of this kind of writing occurs when the doctor and Carolina describe the poet's childish personality and the silly games his secretary found to entertain him. The use of fast poetic rhythms, with three syllables per line, as well as word playing, simulate children's songs and games:

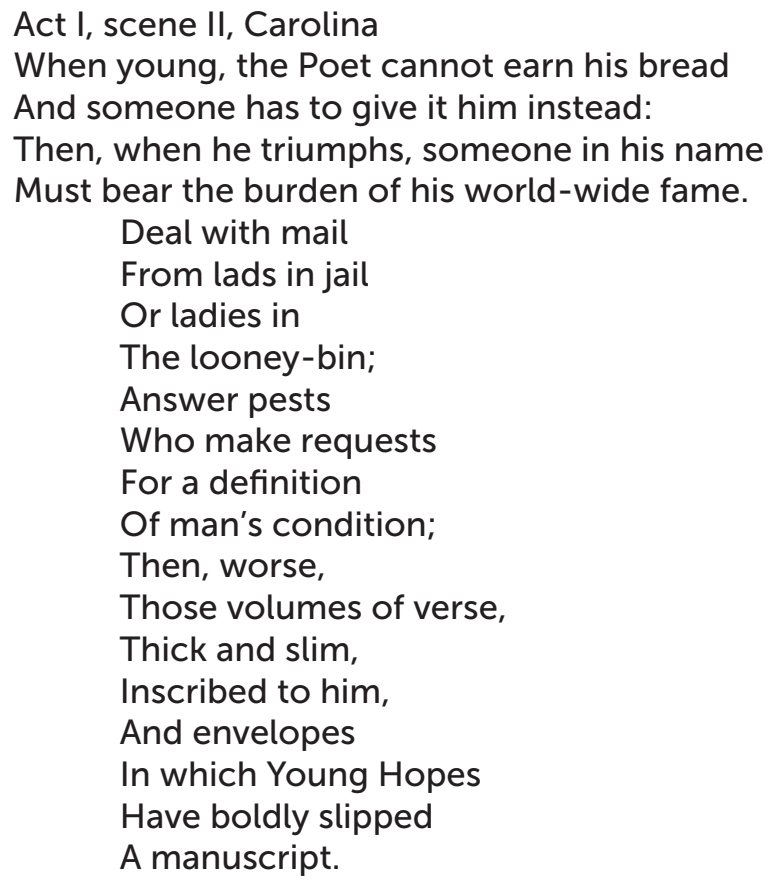

Without me, when would Genius turn a rhyme?

It would be answering letters all the time (HENZE, 1989, p. 11).

Finally, let us look at the allusions to secondary worlds within the text of the love duet, which contains, as mentioned above, references to two opera topics in the same music. Saying goodbye to the primary world, the lovers realize that the romantic love and life they imagined for themselves were illusory, nothing but creations of their minds:

Not for love were we led here,

But to unlearn our lies,

Each through each, in our last hour,

And come to death with clean hearts.

What Grace gave, we gladly take,

Thankful although even this

Bond will break in a brief while,

And our soul fare forth alone.

God of truth, forgive our sins,

All offences we fools made

Against thee. Grant us Thy peace.

Light with Thy Love our live's end (HENZE, 1989, p. 58). 
In addition to the illusion of love, still another instance of a secondary world seems to be hidden in the text, highlighted by the expression "God of truth", which points out to Auden's interest in the writings of Kierkegaard and his criticism of the bourgeois false view of Christianity. Let's look at a few passages written by Auden in his introduction to the book The Living Thoughts of Kierkegaard (AUDEN, 1999, xxiv):

The danger for the Christian in an officially Christian society is that he may think he is a Christian. But nobody except Christ and, at the end of their lives perhaps, the saints are Christian [...] He may think he believes as an individual when all he is doing is believing what his parents said [...] The world has changed greatly since Kierkegaard's time and all too many of his prophetic insights have come to pass. The smug bourgeois Christendom he denounced has crumbled and what is left is an amorphous, despairing mass of displaced persons and paralyzed Hamlets.

In the second half of the 20th century, the use of material from the past to expand the dramatic musical language was no longer an original idea, as we can tell from the references to ancient dances in Wozzeck or the neo-classical procedures in Rake's Progress. On this subject, Robert Hatten raises relevant questions in his article about pluralism in Henze's opera We Come to the River: "Is pluralism an admission of the poverty of dramatic range within a given twentieth-century style? [...] Is pluralism in opera simply a consequence of the need to paint with broad strokes to guarantee a wider audience for what has traditionally been a more popular genre?" (HATTEN, 1990, p. 309-310).

Perhaps, Henze's compositional pluralistic approach was related to his concernment about the outreach potential of this work, as can be seen by his care with the feasibility of its performance. Besides its chamber conceptions, he writes, for instance, an instruction in the list of instrumentation (see Tab. 1) about the substitution of the flexatone by an electronic device, which reads: "può essere sostituito da uno strumento elettronico"10 (HENZE, 1989, vi). Further evidence of his concern with the question of accessibility of his compositions can be found in his suggestions of alternative venues for the performance of his opera Natascha Ungeheuer, such as outdoor gymnasiums and concert platforms, in the lack of a suitable theatre (BERRY, 2014, p. 100). This could also lead to to the reasons why Elegy's original libretto was written in English, with German translation. Considering that Auden and Kallman were already known in the music scene as the authors of Stravinsky's Rake's Progress libretto (1951), and that Britten's English operas were highly in vogue in Europe, perhaps it might have been convenient to write an opera in English, to facilitate its entry into the artistic circles.

Even if the use of materials from different traditions or different styles is guided by Henze's concern with representation and dramatization, and not by postmodern trends, 
as it was suggested by Hatten, ${ }^{11}$ interactions with other traditions appear on both literary and musical levels, being employed in Elegy for Young Lovers to construct a didactic discourse. This is an opera that talks about its own genre, a libretto that describes the making of a libretto, and above all, it is about poets who write about the life and obsessions of another poet. To conclude, Henze says "we can look back as if the whole work were conceived as a didactic piece", while we ironically look at the figure of the artist as a hero, portrayed in the opera, as a concept created by the 19th century "not yet completely abandoned by the twentieth" (HENZE, 1982, p. 111).

\section{Bibliography}

AUDEN, W. H. Secondary worlds. London: Faber \& Faber, 1984.

AUDEN, W. H., ed. The Living Thoughts of Kierkegaard. Introduction by W. H. Auden. New York: The New York Review of Books, 1999.

BERRY, M. Hans Werner Henze: paths to (and From) Natascha Ungeheuer. After Wagner: Histories of Modernist Music Drama from Parsifal to Nono, Woodbridge, Suffolk, UK; Rochester, NY, USA: Boydell \& Brewer, p. 172-204, 2014. Accessed April 26, 2020. DOI:10.7722/j.ctt6wpbcx.13.

COOKE, M. ed. The Cambridge Companion to Twentieth century opera. Cambridge/ New York/ Melbourne: Cambridge University Press, 2005.

EDGECOMBE, Rodney, Stenning. Topoi and melodic morphology in the operas of Donizetti. The Musical Times, 155, no. 1926 (2014): 67-80. Accessed April 26, 2020. www.jstor.org/stable/24615705.

FULLER, J. W.H. AUDEN: a commentary. Princeton Oxford, University Press: 1998.

HENZE, H.W. Elegy for Young Lovers. Opera in three acts by W. H. Auden and Chester Kallman. Mainz: Schott, 1989.

HENZE, H.W. Elegy for Young Lovers. (1959/61-Revised Version 1989). Opera in three acts by Wystan H. Auden and Chester Kallmann. Deutsche Fassung von Ludwig Landgraf unter Mitarbeit von Wener Schachteli und dem Komponisten. Study Score. (ED 8776) Mainz/ London/ Madrid.

11 "Henze does not employ the quotation and play of allusion to specific works that characterizes a certain species of postmodernism, but rather employs stylistic pastiche and parody as means of musical representation and dramatization" (HATTEN, 1990, p. 293). 
HENZE, H.W. Elegy for Young Lovers. Revised Version 1987. Opera in three acts by Wystan H. Auden and Chester Kallmann. Revised Version 1987. Deutsche Fassung von Ludwig Landgraf unter Mitarbeit von Wener Schachteli und dem Komponisten. Klavierauszug von Markus Lehmann. Study Score. (ED 5100) Mainz/ London/ Madrid.

HENZE, H. W. Music and Politics. Collected Writings 1953-1981. Translated and edited by Peter Labanyi. London: Faber \& Faber, 1982.

HATTEN, R. S. Pluralism of Theatrical Genre and Musical Style in Henze's "We Come to the River." Perspectives of New Music, vol. 28, no. 2 (Summer, 1990): 292-311.

HUOVINEN, E., KAILA, A.. The Semantics of Musical Topoi: An Empirical Approach. Music Perception: An Interdisciplinary Journal 33, no. 2 (2015): 217-43. Accessed April 29, 2020. doi:10.1525/mp.2015.33.2.217.

LACHENMANN, H.; STADELMAN, J. Open Letter to Hans Werner Henze. Perspectives of New Music, vol. 35, no. 2 (Summer, 1997): 189-200.

MICZNIK, V. Of Ways of Telling, Intertextuality, and Historical Evidence in Berlioz's "Roméo et Juliette." 19th-Century Music 24, no.1 (2000): 21-61. Accessed April 29, 2020. doi:10.2307/746871.

NORTHCOTT, BAYAN, STRAVINSKY, HENZE. Notes on Auden: 2. Life after Britten? Bayan Northcott Completes His Survey of Auden's Life in Music by considering the Poet's Collaborations with Stravinsky, Henze, and Others. The Musical Times, vol.134, no.1800 (February 1993): 68-72.

PETERSEN, Peter. “Henze, Hans Werner.” MGG2: 1325-1352.

PORTER, A. Elegy for Young Lovers. The Musical Times, vol. 102, no. 1421 (July 1961): 418-419.

PORTER, A. Henze's 'Young Lord'. The Musical Times, vol. 110, no. 1520 (October 1969): 1028-1030.

SHAKESPEARE. Macbeth. Available from https://www.opensourceshakespeare.org/views/plays/play_view. php? WorkID=macbeth\&Scope=entire\&pleasewait=1\&msg=pl\#a5,s5 (accessed April 29, 2020).

ROTH, M. A. The Sound of a Poet Singing Loudly: A Look at "Elegy for Young Lovers". Comparative Drama, vol. 13, No. 2 (Summer, 1979): 99-120. 
THEILACKER, J. B. 'Grazie und Härte, Kühle und Feuer' Gegensätze in Henzes Oper Der Prinz von Homburg. In Theater ist ein Traumort. Opern des 20. Jahrhunderts von Janáček bis Widmann, herausgeben von Hanspeter Krellmann und Jürgen Schläder (Berlin: Henschel, 2005): 213-217.

WALTER, B. “Prekäre angewandte Opernästhetik: Audens 'sekundäre Welt' und Hans Werner Henzes Elegie für junge Liebende". In Die Semantik der musiko-literarischen Gattungen: Methodik und Analyse; eine Festgabe für Ulrich Wisstein zum 65.

Geburtstag. Herausgegeben von Walther Berhart, 233-246.Tübingen: Narr, 1994.

WHITTALL, A. Henze's Haunted Sensibility. The Musical Times, vol. 147, no. 1895 (Summer 2006): 5-15. 